\title{
Mississippi: Republicans Surge Forward in a Two-Party State
}

\author{
Stephen D. Shaffer, David A. Breaux, and Barbara Patrick
}

\section{Political Context}

Mississippi entered the 21 st century as a competitive two-party state far removed from its post-Reconstruction history of one-party Democratic domination. Yet Republican gains which had led to this emerging parity between the parties were not uniform across elective offices, as they had come first in federal elections and only later trickled down to state offices (Aistrup 1996). Mississippi voted Republican for president for the first time since Reconstruction in 1964 and 1972 (by landslide margins), narrowly backed Democrat and born-again southern Baptist Jimmy Carter in 1976, and henceforth has cast every one of its electoral votes for Republican presidential candidates. Enduring U.S. House gains began occurring in the Nixon landslide reelection year of 1972 with victories by Republicans Thad Cochran and Trent Lott. Cochran and Lott then replaced retiring conservative Democratic U.S. senators James Eastland in 1978 and John Stennis in 1988. Democrats remained competitive in U.S. house races at the century's end, however, retaining two moderate conservative whites (Ronnie Shows and Gene Taylor) and one liberal African American (Bennie Thompson, representing the black majority "Delta" district) as congressmen. With the retirements of boll weevil Democrats Jamie Whitten in 1994 and Sonny Montgomery in 1996, conservative Republicans Roger Wicker and Chip Pickering took their places to maintain two House seats for the GOP.

In state offices, Republican gains were not as noticeable until the last decade of the 20th century (Table 1). An economic recession that had produced two years of painful budget cuts in popular state programs including public education from kindergartens to universities led voters in 1991 to oust two Democrats - Governor Ray Mabus and Lieutenant Governor Brad Dye. The first Republican governor in Mississippi since Reconstruction, conservative businessman Kirk Fordice, was then reelected in 1995 during a booming economy, though Democratic state senator Ronnie Musgrove upended the Magnolia State's first GOP lieutenant governor, Eddie Briggs.

StePhen D. SHAFFer and DAvid A. BreAux are professors of political science at Mississippi State University. BARbara A. PATRICK is a Ph.D. student in the Public Policy and Administration program at Mississippi State University.

The American Review of Politics, Vol. 26, Spring, 2005: 85-107

(C)2005 The American Review of Politics 
Table 1. Two-Party Competition for State Offices

\begin{tabular}{|c|c|c|c|c|c|c|}
\hline \multirow[b]{2}{*}{ Year } & \multicolumn{2}{|c|}{$\begin{array}{c}\text { Governor Vote } \\
\text { (\% of major two party) }\end{array}$} & \multicolumn{2}{|c|}{$\begin{array}{c}\text { Popular vote for } \\
\text { Lieutenant Governor } \\
\text { (\% of major two party) }\end{array}$} & \multicolumn{2}{|c|}{$\begin{array}{l}\text { Party Control of Eight } \\
\text { Statewide Offices }\end{array}$} \\
\hline & Rep. & Dem. & Rep. & Dem. & No. of Rep. & No. of Dem. \\
\hline 1983 & 41.4 & 58.6 & 0 & 100 & 0 & 8 \\
\hline 1987 & 46.6 & 53.4 & 19.4 & 80.6 & 0 & 8 \\
\hline 1991 & 51.6 & 48.4 & 54.4 & 45.6 & 2 & 6 \\
\hline 1995 & 55.6 & 44.4 & 47.3 & 52.7 & 2 & 6 \\
\hline 1999 & 49.4 & 50.6 & 47.1 & 52.9 & 1 & 7 \\
\hline 2003 & 53.4 & 46.6 & 62.2 & 37.8 & 4 & 4 \\
\hline
\end{tabular}

Note: Eight offices that are elected statewide in Mississippi include governor, lieutenant governor, attorney general, secretary of state, treasurer, auditor, insurance commissioner, and agriculture commissioner. These elections, as well as elections for all state legislators, occur every four years in the November before the presidential election year.

Source: Mississippi Official and Statistical Register, 1980-1984 thru 2000-2004, Secretary of State of Mississippi.

The last election of the 20th century was even more bleak for state Republicans, as Musgrove upset Democrat-turned-Republican former congressman Mike Parker for the governorship, and Democrats held on to the lieutenant governorship by electing moderate Amy Tuck. Only the reelection of Phil Bryant as auditor permitted Republicans to retain one of the eight state offices that Mississippi elects from a statewide constituency. And despite fairly steady GOP gains since the 1970s, at the turn of the century Democrats continued to control 65 percent of state senate seats and 73 percent of state house seats (Shaffer and Price 2001; Shaffer, Pierce, and Kohnke 2000).

And then the governing Democratic coalition in state elections began to unravel. Governor Musgrove delivered on his campaign pledge to raise public elementary and secondary teachers' salaries to the Southeast average over six years without raising taxes, but a post 9-11 recession produced three years of painful budget cuts in higher education and other state programs. With the loss of one of the state's five U.S. house districts after reapportionment, either Democrat Shows or Republican Pickering was slated to lose his seat, and activist Democrats urged their party's lieutenant governor (who as president of the state senate exercises considerable power in the upper chamber) to back a state house redistricting plan that created a "shoestring" district that would benefit Shows. The independent-minded lieutenant governor, "country gal" Amy Tuck, responded to concerns by city officials that major cities not be lumped into the same district, and rebuffed Democratic 
activists. After Shows' defeat by Pickering in the 2002 elections, the proeducation but socially conservative Tuck, who had also angered liberals by supporting tort reform, switched her affiliation to the Republican Party (Goodman 2002).

As the 2003 state elections loomed, Republicans attracted lobbyist and former Republican National Committee chair during the party's monumental 1994 successes nationally, Haley Barbour, as their gubernatorial challenger to Musgrove. For their challenger to Lieutenant Governor Tuck, Democrats nominated a bright, articulate, and accomplished state senator, Barbara Blackmon, who was also a Black Caucus member with a liberal voting record. Reeling from Barbour's charges that the governor had produced a massive state deficit through mismanagement, overspending, and failing to attract enough jobs to the state, Musgrove's camp ran television ads that blasted Barbour as a "Washington lobbyist," with some ads not even mentioning the governor's name and one ad even accusing Barbour of helping "tobacco companies poison our kids" (Gray 2003, 1). Meanwhile, Blackmon reacted to Tuck's claim that Tuck was pro-life and that Blackmon had more liberal views by challenging the divorced lieutenant governor to sign an affidavit that she had never had an abortion. As political observers denounced Blackmon's getting too personal and Tuck viewed the challenge as "innuendo" that she had had an abortion, the lieutenant governor nevertheless signed the oath and announced that she was "pro-life in my private life and I am pro-life in my professional life" (Byrd 2003, 3B).

November 2003 was a good month for Mississippi Republicans, as for the first time the party won half of the state's eight executive offices. A strong party grassroots turnout-the-vote drive that canvassed neighborhoods the weekend before the election helped lift Barbour to a comfortable victory over Governor Musgrove, while incumbent Republicans Amy Tuck and Phil Bryant were reelected lieutenant governor and auditor, respectively. Republicans split two open races, winning the treasurer's race with a better funded candidate, Tate Reeves, defeating a well-qualified African American, Gary Anderson, but losing the attorney general's race to an experienced prosecutor, Jim Hood. In addition to Hood's victory, Democrats also reelected Secretary of State Eric Clark, Agriculture Commissioner Lester Spell, Jr., and Insurance Commissioner George Dale. While Anderson was gracious in defeat, Blackmon retorted that "if my pigmentation were different, I would be the lieutenant governor of this state," though prominent state columnist Sid Salter a month previously had concluded that Blackmon's miscue on the abortion issue had "backfired big time" and that Tuck was now "almost sure to be re-elected" (Anderson 2003; Blackmon quotation in Associated Press 2003; Salter quotation in Salter 2003). Republicans also made gains in the state legislature, winning 23 of the 52 senate seats and 46 of the 122 house seats, though Democrats retained control of both chambers. 
As the 2004 presidential election year began, political observers expected another bleak year for Mississippi Democrats. Not since 1976 had Mississippi voted for a Democratic presidential candidate. Beginning with Reagan's landslide victory in 1984 Mississippi had voted more Republican than the nation as a whole each year (Table 2). Indeed, beginning with Vice President Bush's victory in 1988, Mississippi had even been voting more Republican than the South (11 Confederacy states). With a close election expected nationally, as in 2000, if Mississippi voted 9 percent more Republican than the national average, as it had in 2000, the state would clearly be considered a safe one for the GOP. Democratic presidential hopes rested with trying to resurrect the type of competitive situation that existed in Mississippi and the South before 1984, when the Magnolia State first backed Carter by a one-percent margin and then Reagan by the same slim margin. To add to Democratic nightmares, state Republicans were hoping to field strong challengers to the two remaining Democrats in federal office, liberal African American 2nd district congressman Bennie Thompson and moderate conservative 4th district congressman Gene Taylor.

Democrats were even losing ground on the basic indicator of party identification among the eligible electorate. As late as 1990 in Mississippi, Democrats outnumbered Republicans by a 20 percent margin (Table 3 ). The year after the election of two Republicans as governor and lieutenant governor, the Democratic advantage in partisanship slipped to single digits. After Governor Fordice's controversial divorce and Musgrove's initial popularity as the newly elected governor, Democrats regained a double digit lead in partisanship (Shaffer and Price 2002, 100). By 2002 Democrats had lost their plurality to the GOP, which opened up a statistically insignificant edge in public support, a narrow Republican advantage that remained in the latest 2004 poll conducted in April. Yet one bombshell erupted the very next month after the legislature adjourned, an explosion of public anger over Governor Barbour's initially successful effort to transfer thousands of elderly Mississippians from the Medicaid program to Medicare. Thus began months of public protests and angry letters to the editor by senior citizens objecting to losing coverage for some medical procedures that Medicare did not cover. Whether this controversy would increase the salience of such popular domestic spending programs as health care and education to Mississippi voters, thereby benefiting Democratic candidates who historically took more progressive positions on such New Deal kinds of issues, was one "wild card" in the electoral equation.

\section{The Presidential Primaries and Conventions}

Given Mississippi's reputation as a Republican stronghold in presidential elections, presidential hopefuls spent little time in the state. Vice 
Table 2. GOP Presidential Election Votes in Mississippi, the South, and the Nation

\begin{tabular}{lccccc}
\hline $\begin{array}{l}\text { Year of } \\
\text { Election }\end{array}$ & Miss & South & Nation & $\begin{array}{c}\text { Miss } \\
\text {-South }\end{array}$ & $\begin{array}{c}\text { Miss } \\
\text {-Nation }\end{array}$ \\
\hline 1976 & 49.0 & 45.2 & 49.0 & +3.8 & 0 \\
1980 & 50.7 & 53.6 & 55.3 & -2.9 & -4.6 \\
1984 & 62.3 & 62.6 & 59.2 & -0.3 & +3.1 \\
1988 & 60.5 & 58.8 & 53.9 & +1.7 & +6.6 \\
1992 & 54.9 & 50.8 & 46.5 & +4.1 & +9.4 \\
1996 & 52.7 & 49.9 & 45.3 & +2.8 & +7.4 \\
2000 & 58.6 & 55.5 & 49.7 & +3.1 & +8.9
\end{tabular}

Note: Cell entries in the first three columns are the percentage of the two-party vote won by Republican Presidential candidates. The last two columns reflect deviations between Mississippi and the 11 southern states and the entire nation (positive signs indicate that Mississippi is more Republican than the region or nation).

Source: Pomper 1981, 68-69; Abramson, Aldrich and Rohde 1986, 68-69; Stanley 1994, 203; Stanley 1997, 227; Stanley 2002, 220.

Table 3. Party Identification among Adult Mississippians

\begin{tabular}{lcccc}
\hline Year of Survey & Democrat & Independent & Republican & Party Edge \\
\hline 1981 & 61 & 7 & 32 & $29 \mathrm{D}$ \\
1982 & 61 & 14 & 25 & $36 \mathrm{D}$ \\
1984 & 56 & 15 & 29 & $27 \mathrm{D}$ \\
1986 & 54 & 10 & 36 & $18 \mathrm{D}$ \\
1988 & 53 & 13 & 34 & $19 \mathrm{D}$ \\
1990 & 56 & 8 & 36 & $20 \mathrm{D}$ \\
1992 & 47 & 13 & 40 & $7 \mathrm{D}$ \\
1994 & 47 & 12 & 41 & $6 \mathrm{D}$ \\
1996 & 48 & 10 & 42 & $5 \mathrm{D}$ \\
1998 & 47 & 11 & 42 & $12 \mathrm{D}$ \\
1999 & 51 & 10 & 39 & 2R \\
2000 & 54 & 6 & 40 & $3 R$ \\
2002 & 45 & 8 & 47 & \\
2004 & 43 & 11 & 46 &
\end{tabular}

Note: Cell entries total $100 \%$ across each row. The last column is the percentage difference between Democratic and Republican identifiers. The standard seven point party identification question asked adult Mississippians if "Generally speaking, do you consider yourself a Democrat, Republican, Independent, or what?" Those responding Independent were asked, "Do you think of yourself as closer to the Democratic party or the Republican party?" Independent leaners were classified as partisans because of their tendency to behave in a partisan manner.

Source: Mississippi State University, Social Science Research Center statewide polls (cited in http://www2.msstate.edu/ kauai/poll/pressrelease04.html). 
President Dick Cheney spoke to a state Republican fundraiser in December 2003, touting a growing economy, passage of the Medicare reform act, and an "outstanding" Cabinet team as reasons to re-elect President Bush. Responding to Howard Dean's frontrunner status, Congressman Chip Pickering set the stage for the general election campaign by blasting the national Democratic Party for having "written off the entire South-they have gone to the most liberal wing of the Democratic Party" (Kanengiser 2003, 12A). Later that month, as Dean supporters hosted a half dozen fundraising parties across the state, General Wesley Clark addressed a rally at the War Memorial Building in Jackson. Clark claimed that his campaign stood for faith, family, and the American flag, and he bashed Bush for leaving two million children without health insurance and letting the hunt for Osama Bin Laden be diverted by war in Iraq. Touting Clark as the true southerner in the race, Congressman Gene Taylor asserted that "When George Bush was chasing girls at Yale, Wes Clark was chasing Vietcong in Vietnam" (Minor 2004a, 3G).

John Kerry's victories in Iowa, New Hampshire, and other early nomination contests energized his supporters in Mississippi. The state cochairman for the Kerry campaign, former state representative Bill Wheeler, touted Kerry as a hunter who drove a pick-up truck. Wheeler blasted Bush for the worst performance in creating jobs since Herbert Hoover, and he charged that the Bush team had given big corporations tax breaks for moving jobs overseas while forcing the elderly to go to Canada to obtain reasonably priced prescription drugs (Wheeler 2004). As Kerry became the Democratic frontrunner, Governor Barbour praised Bush's tax cuts for causing an economic turnaround, and blasted Kerry as "the ideological twin of Teddy Kennedy. . . . In fact, Kerry is probably the more liberal senator from Massachusetts" (Associated Press 2004a, B1).

Two days before the March 9 Mississippi primary, Kerry's visit to historically black private Tougaloo College in Jackson was overshadowed by the anti-gay marriage state constitutional amendment that would be on the November ballot. Responding to an older black woman who asserted that "Most of the people in this country are sick and tired of the onslaught of the homosexual community using the civil rights movement to further their agenda," Kerry argued that discrimination against gays should be taken as seriously as discrimination against African Americans and backed gay couples having some of the same rights as straight couples (Goodman 2004a, 1). Meanwhile, state Republican Party chair Jim Herring blasted Kerry's promise to roll back the Bush tax cuts for the wealthy: "It sounds to me like he wants to raise taxes and he's using the tactics of most liberal Democrats which is to engage in class warfare by trying to pit one group against another" (Pettus 2004a, 6A). As Kerry continued to sweep primaries, 
he won Mississippi's with 78.4 percent of the vote to 7.3 percent for John Edwards, 5.2 percent for Al Sharpton, and 9.1 percent for five other candidates and the uncommitteds.

As Kerry amassed enough delegates nationally to become the party's presidential nominee, a statewide poll conducted by Mississippi State University (MSU) found him trailing badly in the Magnolia state with only 30 percent of the vote to 61 percent for Bush with 9 percent undecided, suggesting yet another easy Republican win (see the website http://www2.msstate. edu/ kauai/poll/pressrelease04.html). State Democrats valiantly battled on with Congressman Bennie Thompson charging that Bush had "run away from conservative values" by ringing up huge deficits through "reckless spending" (Kanengiser 2004a, 3B). Speaking to local Democrats, Kerry's state co-chair Bill Wheeler portrayed Kerry as having a "mainstream message about what's fair to the middle class and working people," while blasting the Bush administration as uncaring of the "working middle class and the poor" (Hawkins 2004a, A11 first quotation, A1 second quotation). Speaking to the state Democrats' Jefferson-Jackson-Hamer day dinner, Wesley Clark underscored Bush failures by pointing out the need for a larger military and for more international cooperation in post-war Iraq (Clark 2004).

Kerry's vice presidential pick of southerner John Edwards buoyed state Democrats with incoming state Democratic chair Wayne Dowdy, a folksy and moderate former congressman, praising the "enthusiasm and excitement" that he would bring to the ticket. Republican state party chair Herring responded by bashing Edwards as a "trial lawyer" who was "one of the ringleaders to bring down the nomination of Judge Pickering," a federal district judge and father of Congressman Pickering whose nomination to a federal appeals court had been blocked by Democratic U.S. senators (Fuquay 2004a, 1). State Democratic chair Dowdy proceeded to denounce Republican governor Barbour for cutting elderly people from the state Medicaid program and claimed that Democrats were the party that "looks out for the needs of people, the little people" (Minor 2004b, 3G).

State Democrats touted their party's reflection of Mississippi's diversity with 24 of the state's 41 national convention delegates being black and 21 being women, compared to only 15 women and 5 blacks, 1 Hispanic, and 1 American Indian among the 38 Republican convention delegates (Fuquay $2004 b, 1)$. Returning home from the convention, Dowdy fired up his troops by charging that "Under the Bush administration, we have seen huge surpluses turn into huge deficits, we have seen our emergence as policeman of the world, and we have seen unprecedented losses of jobs" (Fuquay 2004c, 1, 4A). The only statewide elected Democrat to attend the national Democratic convention, Attorney General Jim Hood, argued that "If you're not 
making \$200,000 a year, you need to be voting Democratic" (Pettus 2004b, 7A).

As the national Democratic convention came to a close, Republicans bashed Kerry at the Neshoba County Fair, Mississippi's annual "Giant House Party." To loud applause from fairgoers, Senator Trent Lott ridiculed the Democratic presidential candidate as "a French-speaking socialist from Boston, Massachusetts, who's more liberal than Ted Kennedy" (Kanengiser 2004b, 1). Governor Barbour blasted Kerry as "Teddy Kennedy's ideological twin. Kerry is just the taller, thinner version." Underscoring the Democrat's image as a flip-flopper, Barbour concluded, "The only difference between Kennedy and Kerry is that, if Kennedy tells you something, you can count on it" (Kanengiser 2004c, B1). Democrats were dealt yet another blow when the state's longest serving Democratic statewide officeholder, Insurance Commissioner George Dale, endorsed Bush, denouncing John Edwards' opposition to judge Pickering's nomination and Kerry's flipflop in voting to authorize the Iraq war but then refusing to fund it.

Mississippi Republicans were the more united party in support of their presidential nominee, as in previous years, and their national convention highlighted some positive attributes of their party. The national party recognized Mississippians' importance by making Barbour chair of a platform subcommittee on families, which adopted the party's usual pro-life plank and backed the Defense of Marriage Act which Kerry had opposed (Salter 2004). In contrast to the state Democrats, all four statewide elected Republicans were delegates to the convention, as were both U.S. Senators and both GOP congressmen. The state press reported the convention speech by Education Secretary and former Jackson State University football coach Rod Paige, which lauded Bush's effort to improve education by stressing accountability and tougher testing standards (Kanengiser 2004d). Some delegates attended a luncheon with the Bush daughters where Laura Bush claimed that her husband "understands the importance of empowering women. And he has three strong women at home who will not let him forget it" (Sabbath 2004, A4). By Labor Day, Bush's prospects appeared so strong in Mississippi that Governor Barbour and Congressman Pickering were both scheduling speaking engagements in "battleground states," while MSU College Republicans also made plans to campaign in states such as Florida and Tennessee.

\section{Waging a Presidential Campaign in a "Safe" State}

As in the two preceding presidential election campaigns, national Democrats virtually wrote off Mississippi with the only prominent party figure campaigning in the Magnolia State being Vice Presidential nominee 
John Edwards' wife, Elizabeth. Speaking to the press after a private fundraiser, Mrs. Edwards, whose mother hails from Hazlehurst Mississippi, criticized the Bush administration's cuts in the Veterans Affairs Department and pledged that John Kerry would unify a "highly divided country" by being "president of all the people" (Byrd 2004a, 3B). State and local Democrats valiantly took up the slack, blasting Bush and boosting the Kerry-Edwards ticket.

State Democratic Party chair Wayne Dowdy traveled across the state speaking to the press, the party faithful, and to anyone interested in politics. At an MSU event, the folksy Dowdy bashed Bush for the large federal deficit, predicted that Kerry would be a second JFK, and compared party politics to an automobile transmission: "You put it in $\mathrm{D}$ to go forward and $\mathrm{R}$ to go in reverse" (Jones 2004, 1). At a Northeast Mississippi Democratic Party Rally and Unity Dinner in Tupelo two weeks before the election, Dowdy credited Democrats with understanding that "the role of government is to provide a ladder so people can improve their lives" (Faulkner 2004,1). At the same event, former governor Ronnie Musgrove blasted Bush as "King George," assailed his "failed" policies on education, health care, and foreign policy, and predicted that the battle for American independence would shortly be fought at the ballot boxes. At the county level, Democratic county chairs and committee members were quoted in local newspaper articles and wrote letters to the editor denouncing Bush administration policies and backing Kerry-Edwards.

Two political fiascoes for Republicans offered some last-minute hope to Mississippi Democrats. Attorney General Jim Hood, a prominent Democrat, was successful in convincing a Republican-appointed federal judge to block Governor Barbour's proposed cuts in Medicaid which had been enacted by the legislature, resulting in front page pictures of grateful senior citizens, including one hugging the victorious Hood (Kanengiser 2004e). Barely two weeks before the election, state newspapers provided front-page coverage of a supply platoon in Iraq that included Mississippi reservists that had refused a mission because of their poorly maintained and protected vehicles. One Jackson area wife was even quoted complaining that the soldiers had been "arrested on a bogus charge because they refused to go on a suicide mission" (Hudson 2004, 8A). A labor union rally in Pascagoula on the Gulf Coast summed up key Democratic arguments against Bush with labor union spokespersons lamenting the loss of jobs during the Bush years, expressing the fear that "Social Security won't be there at all when I retire," and accusing Bush of "carelessness with our sons and our daughters (at war) now" (Baker 2004, 4A).

The state Republican Party organization had its usual effective campaign machine revved up. Retiring U.S. Senator Zell Miller, a Democrat 
who at the national Republican convention had blasted the liberal direction of his party, headlined a state GOP fundraiser in Jackson that netted $\$ 350,000$. Blasting Kerry's senate record as one of "tax, spend, redistribute income," and claiming that the Democrat believed "if you rob Peter to pay Paul, Paul will vote for you," Miller praised Bush as a leader in the war on terrorism who "won't waver, wobble or go weak in the knees" (The ClarionLedger 2004a, 2B). State Democratic chair Dowdy promptly responded that Miller was "a great embarrassment to me. He got his start with Lester Maddox and he's not strayed far from it" (Kanengiser 2004f, 2G). State Republicans also hosted a rally at the State Capitol with more than forty Democratic public officials endorsing Bush. Joined by Transportation Commissioners Bill Minor and Wayne Brown and such prominent former elected officials as Lieutenant Governor Brad Dye, House Speaker Tim Ford, state Supreme Court justices Lenore Prather and Jim Roberts, and Jackson Mayor Dale Danks, former Congressman Sonny Montgomery urged Mississippi voters to "look beyond political party and instead at qualifications and proven leadership" (East Mississippi Business Journal 2004, 23).

Prominent Mississippi Republicans, such as Thad Cochran who chaired the Senate Appropriations Subcommittee on Homeland Security, also weighed in on the election. In a meeting with the Northeast Mississippi Daily Journal editorial board in Tupelo, the Republican senator pledged that the federal government was "meeting the challenge posed by terrorist threats" and predicted that Bush would win every southern state (McKenzie 2004, 8A). In a press interview before an MSU event, Cochran pointed to Interim Iraqi leader Allawi's upbeat speech to Congress as a reminder that the Iraqi people were better off today because of American leadership in removing Saddam Hussein from power, and he forecast that a democratic Iraq could have a positive long-term impact in bringing greater peace and stability throughout the troubled Mideast (Hawkins 2004b).

State Republican leaders effectively sharpened their message for reelecting Bush. In an interview with the East Mississippi Business Journal, GOP chair Herring stressed that America was "in a great war on terrorism and also a great cultural war" that Bush was "best equipped to fight and win," and he repeated the words "war" and "terrorism" throughout the interview (Smith 2004, 7). At the fall "Issue Stew" sponsored by the Oktibbeha County Republicans and MSU College Republicans, Lieutenant Governor Amy Tuck proclaimed that the Republican Party was pro-life and represented "the majority and the values of Mississippi," and she expressed the hope that Republicans would vote to ban same sex marriage (Starkville Daily News 2004, 1). She summed up her support for Bush's re-election by stressing Bush's character and moral values: "He supports fighting terror abroad and does not sit and wait for it to come to us. He is not afraid to 
admit that he prays. He wants to keep 'under God' in our pledge of allegiance" (Starkville Daily News 2004, A7). Days before the election, Republican Party supporters received mailings from the state Republican Party, one urging a vote for Bush and the other a vote not only for Bush-Cheney but for other Republican candidates and for the state constitutional amendment to ban same sex marriage.

As the campaign entered the final week, polls suggested that the gap in Mississippi was closing. A mid-September American Research Group poll had Bush with only a 9-point lead over Kerry, and a mock election vote by high school students conducted by the Secretary of State's office had Bush with only a 1-point lead (see the updated web site: http://www2.msstate.edu/ حkauai/poll/pressrelease $04 . \mathrm{html}$ ). Newspapers that endorsed Bush suggested a lack of enthusiasm for their pick with headlines such as "Kerry no solution to Bush mistakes" and "Bush: Good enough to give second term." The major statewide newspaper, The Clarion-Ledger, published in the state capital of Jackson, dismissed Kerry as "inconsistent," "reactive," and failing to inspire confidence, while praising Bush as being "resolute and determined in the war on terrorism" having been "tried under the fire of national crisis" (The Clarion-Ledger 2004b, 6G). The Greenwood Commonwealth also expressed mixed feelings, but pointed out that, since 9-11, there "has not been a single act of terrorism on the homeland" and concluded that "at a time of war, it's better to have a resolute chief executive than one whose convictions seem only as firm as the latest political winds" (The Greenwood Commonwealth 2004a, 4A).

\section{Congressional Campaigns: Incumbency Resists GOP Trend}

Incumbents, seeking reelection in all four congressional districts, were so entrenched that only two faced major party opposition in 2004. Republican congressmen Roger Wicker (1st district) and Chip Pickering (3rd district), having bested Democratic opponents two years earlier with 71 percent and 64 percent of the vote, faced only Reform Party opponents, plus independent Jim Giles in Pickering's case (Hawkins and Nutting 2003). More interesting races were shaping up in the two districts represented by Democrats - the 2nd district represented since 1993 by liberal, African-American Bennie Thompson, and the 4th district represented since 1989 by a moderate conservative white, Gene Taylor. Republicans offered serious challengers in both races. Thirty-five year old Clinton LeSueur, a conservative African American who two years earlier had held Thompson to a mere 55 percent vote total, lowest since his first two elections, promised to be an even tougher opponent this time. Taylor faced an even more conservative opponent than himself, a Republican who was a conservative leader in the state legislature. 
National politics only briefly impinged on the 2 nd district contest. In February at Congressman Thompson's invitation, House Democratic Minority Leader Nancy Pelosi toured the Jackson-Hinds Comprehensive Health Center and attended a Thompson fund-raiser. She pointed out that if Democrats gained control of the U.S. House, Thompson would chair the "very, very important" Homeland Security Committee. Referring to Medicaid recipients as "some of the most vulnerable citizens in this country," Thompson warned Governor Barbour against his proposed cuts in the program: "I can't envision any politician wanting to hurt people who need help" (Goodman 2004b, 3B). Republican challenger Clinton LeSueur briefly addressed the national Republican convention, where he stressed the need for a renewal of moral values: "The very foundation of this great nation is Christianity and the firm belief in Jesus Christ" (Pettus 2004c).

LeSueur continued to focus on the issues of faith, marriage, and family values, telling the Greenville Kiwanis Club after his late arrival that "even animals understand that a male and a female are needed for this type union" (Ervin 2004, A3). After being deluged by 7,000 phone calls, including several from black church representatives, Thompson reversed himself and voted with congressional Republicans for an unsuccessful constitutional amendment to ban gay marriage, explaining that "I vote the interests of my district" (Radelat 2004, B1). The Republican also faced some controversy, as he erected a billboard that read "Vote for congressman, LeSueur," leading Democratic activists to accuse him of misleading voters into believing that he was already congressman. Blasting LeSueur's alleged "campaign of lies," Washington County Democratic chair, Douglas Winston pledged that "We will take the sheet off Mr. LeSueur and let everyone know that he's a Republican" (Associated Press 2004b, 5A).

In two debates, Thompson skillfully related his backing for economic development initiatives that had brought jobs to the district, such as the Mississippi Delta Empowerment Zone Alliance, the Delta Regional Authority, and the promotion of local catfish farms to Wal-Mart (Robinette 2004). When accused of not doing enough to create jobs, Thompson, who had held local, county, and federal offices since 1969, lashed back at his inexperienced challenger: "My opponent has never created a job, never built a house, never paved a street" (Cheseborough 2004, 9A). As LeSueur accused the Democrat of accepting money from a gay rights group, Thompson explained that the real issues for his impoverished district were "jobs, health care, education, and dealing with this war in Iraq." An exasperated Thompson proceeded to lecture his young opponent: "I don't know why you're hung up on sexuality ... I go to a church that teaches tolerance and forgiveness. The venom I hear from you, young man, and then you go talking about Jesus, that's unconscionable" (Cheseborough 2004, 1A, 9A, both quotations). In an 
editorial entitled "LeSueur comes off poorly in debate," the Greenwood Commonwealth editors concluded that the Republican challenger had come off as "intellectually shallow and unschooled on his facts" by claiming that Thompson had visited Iraq when he had really visited the Middle East country of Qatar (The Greenwood Commonwealth 2004b, 4).

As the campaign wound down, incumbency was clearly helping Thompson. He adroitly explained that "I'm not a stranger to the district, that I come home every week to the district," and how he maintained five offices throughout the district and a toll-free phone number (Monroe 2004, 1A). Using a classroom as a backdrop to urge more federal funding for Head Start, Thompson did not even have to ask for anyone's vote. One elderly woman related to the press how Thompson had let her live rent-free in one of his properties after her home had burned down (Byrd 2004b). Endorsing Thompson's re-election, the Clarion-Ledger described the Democrat as a "leader in agriculture" with a "demonstrated passion for the poor" who had "worked with local officials to create jobs in one of the nation's poorest regions" (Clarion-Ledger 2004c, 10A).

Gene Taylor joined Thompson as Democrats targeted for defeat by the National Republican Congressional Committee, given Taylor's votes against the Bush tax cuts and the administration's Medicare drug benefit as well as his representation of a district that Bush had carried in 2000 by a hefty 64 percent popular vote (Radelat 2003). Taylor, a congressman since 1989 whose last two re-election victories were by 75 percent and 79 percent of the vote, defended his votes against these Bush proposals by reiterating his conservative views on the federal deficit, explaining that it was "really wrong to run up the deficit" and to "stick our kids with our bills" (Surratt 2004, 7A). As his Republican opponent, two-term state representative Mike Lott, chairman of the Conservative Coalition, touted his Republican label and pledged to support President Bush's congressional initiatives, Taylor stressed his independent reputation: "I'm an American first who happens to be from South Mississippi. I'm an American who happens to be a Democrat and represents South Mississippi" (Surratt 2004, 1A). Clearly, Lott faced an uphill battle in any effort to paint the pro-life, pro-guns Taylor, who had refused to endorse Kerry or Bush for president, as a "liberal."

Taylor skillfully stressed his service to his constituents. As senior Democrat on the Projection Forces subcommittee of the House Armed Services Committee, a committee which authorizes Navy shipbuilding, Taylor had steered some projects to the coast's Ingalls shipyard. In an interview with the Mississippi Press editorial board in Pascagoula, the congressman took credit for obtaining $\$ 150$ million for the next generation of amphibious warships and passing a defense bill that included nearly $\$ 4$ billion for Navy warship projects for Northrop. Taylor also pointed out that not only was 
Ingalls shipyard important to South Mississippi's economy, but that it was "the state's biggest employer and it provides half of the Navy's fleet" (Surratt 2004, 7A). In endorsing Taylor's re-election, the Jackson ClarionLedger concluded that the "maverick" Democrat had been "a consistent friend to the military retirees living on the coast and strong on constituent services" (Clarion-Ledger 2004d, 6A).

\section{Election Results and Analysis}

The 2004 election results further confirmed that Mississippi has become a Republican bastion in presidential elections. Bush won 59.9 percent of the major party vote in the Magnolia state (Nader and four other minor party candidates garnered less than 1 percent of the total vote), an 8.5 percent margin over Bush's 51.4 percent of the two-party vote nationally and 2.6 percent more than the Republican's 57.3 percent of the two-party vote in the South as a whole. Not only did the results continue twenty-four straight years of Mississippi's electoral votes going Republican, but for the fifth election in a row Mississippi voted more Republican than the nation and even the region as a whole (Table 2). Democrats, relying on their strengths of incumbency and constituency service, were successful in turning back strong challenges at the congressional level, however. Thompson and Taylor were both comfortably re-elected with 58 percent and 64 percent of the vote, respectively. Unopposed by major party challengers, Republican congressmen Wicker and Pickering garnered 79 percent and 80 percent of the vote, respectively. Finally, 86 percent of Mississippians voted for the state constitutional amendment to ban same-sex marriage. ${ }^{1}$

As early as April, an MSU poll had demonstrated one major weakness of John Kerry's-Mississippians' perceptions of his liberalism. In a state where 55 percent of likely voters labeled themselves as "somewhat" or "very conservative" and only 14 percent considered themselves "liberal," Kerry was viewed by 59 percent of voters as "very" or "somewhat liberal." With the ideological self-identification scale in the poll ranging from a low of 1 for very liberal to a high of 5 for very conservative and 3 constituting the moderate category, Kerry's mean score of 2.12 or "somewhat liberal" was far removed from the average Mississippian's ideological mean of 3.63 (on the moderate side of "somewhat conservative"). On the other hand, voters perceived Bush to be their ideological soul mate, having a perceived ideology of 3.66 (2004 Mississippi Poll, Mississippi State University; see Table 4). It is also interesting to observe how state Republican officeholders were also viewed by voters as being ideologically close to both voters and to national GOP candidates. Governor Barbour's perceived ideology was 3.55, while Lieutenant Governor Tuck's was a 3.28. Tuck's more moderate 


\section{Table 4. Voter Ideologies and Perceptions of Candidates' Ideologies (in percent)}

\begin{tabular}{|c|c|c|c|c|c|}
\hline Ideology & $\begin{array}{l}\text { Voter's } \\
\text { Own } \\
\text { Ideology }\end{array}$ & $\begin{array}{l}\text { Perceptions } \\
\text { of Kerry’s } \\
\text { Ideology }\end{array}$ & $\begin{array}{l}\text { Perceptions } \\
\text { of Bush's } \\
\text { Ideology }\end{array}$ & $\begin{array}{l}\text { Perceptions } \\
\text { of Governor } \\
\text { Barbour's }\end{array}$ & $\begin{array}{l}\text { Perceptions } \\
\text { of Lieut. } \\
\text { Gov. Tuck's }\end{array}$ \\
\hline Very Liberal & 3 & 31 & 7 & 6 & 6 \\
\hline Somewhat Liberal & 11 & 28 & 9 & 9 & 10 \\
\hline Moderate & 26 & 13 & 15 & 17 & 26 \\
\hline $\begin{array}{l}\text { Somewhat } \\
\text { Conservative }\end{array}$ & 32 & 8 & 37 & 32 & 28 \\
\hline Very Conservative & 23 & 4 & 23 & 17 & 8 \\
\hline No Opinion & 5 & 16 & 9 & 19 & 22 \\
\hline $\begin{array}{l}\text { Mean Value } \\
\text { of Opinionated }\end{array}$ & 3.63 & 2.12 & 3.66 & 3.55 & 3.28 \\
\hline \multicolumn{6}{|c|}{$\begin{array}{l}\text { Note: Cell entries above Mean Value total } 100 \% \text { down each column. Ideology was determined by } \\
\text { self-identification asking respondents: "What about your political beliefs? Do you consider yourself } \\
\text { very liberal, somewhat liberal, moderate or middle of the road, somewhat conservative, or very } \\
\text { conservative?" } \\
\text { Source: } 2004 \text { Mississippi Poll, telephone survey of } 308 \text { likely voters in April by the Social Science } \\
\text { Research Center at MSU. }\end{array}$} \\
\hline
\end{tabular}

perceived ideology is consistent with her Democratic Party origins and helps explain her electoral strength in 2003 in defeating a liberal Democratic challenger.

Indeed, this marked at least the fifth election in a row that Mississippians perceived the national Democratic Party's presidential candidate as too liberal for them (MSU polls did not include ideological perception questions until 1988). In each of these elections, the Democratic presidential candidate was viewed as being anywhere from somewhat liberal to the midpoint between somewhat liberal and moderate, while the GOP nominee was viewed as being somewhere between moderate and somewhat conservative (Table 5). Since the average Mississippian usually placed himself or herself somewhere slightly to the right-of-center, voters perceived themselves to be ideologically closer to the Republican nominee in each election. Indeed, average voters were generally more than a full point removed in distance from the Democrat, while typically being within two-tenths of a point from the Republican. Such consistency helps explain why Mississippi has not only voted Republican in each election but, in these last five elections, has voted more Republican than the nation and even the southern region. 
Table 5. Voter Ideologies and Perceptions of Presidential Candidates' Ideologies Since 1988 (in means)

\begin{tabular}{|c|c|c|c|c|c|}
\hline Year & $\begin{array}{l}\text { Voter's } \\
\text { Own } \\
\text { Ideology }\end{array}$ & $\begin{array}{l}\text { Perception of } \\
\text { Democrat's } \\
\text { Ideology }\end{array}$ & $\begin{array}{l}\text { Perception of } \\
\text { Republican's } \\
\text { Ideology }\end{array}$ & $\begin{array}{c}\text { Distance: } \\
\text { Voter- } \\
\text { Democrat }\end{array}$ & $\begin{array}{c}\text { Distance: } \\
\text { Voter- } \\
\text { Republican }\end{array}$ \\
\hline 1988 & 3.52 & 2.20 & 3.78 & 1.32 & -.26 \\
\hline 1992 & 3.50 & 2.50 & 3.50 & 1.00 & 0 \\
\hline 1996 & 3.51 & 2.20 & 3.70 & 1.31 & -.19 \\
\hline 2000 & 3.26 & 2.35 & 3.40 & 0.91 & -.14 \\
\hline 2004 & 3.63 & 2.12 & 3.66 & 1.51 & -.03 \\
\hline \multicolumn{6}{|c|}{$\begin{array}{l}\text { Note: The last two columns denote the distances between the average voter's own ideology and thei } \\
\text { perception of the candidates' ideologies. Positive scores indicate that the voter is more conservative } \\
\text { than the candidate's perceived position. The ideology indicator ranges in codes from } 1 \text { for "very } \\
\text { liberal" to } 5 \text { for "very conservative." } \\
\text { Source: Shaffer 1991: } 112 \text {; Shaffer 1994: } 76 \text {; Shaffer and Burnside 1997: } 105 \text {; Shaffer and Price } \\
\text { 2002: } 109 \text {. }\end{array}$} \\
\hline
\end{tabular}

Knowledgeable political observers in Mississippi blasted the "liberal" direction of the national Democratic Party. Former Democratic Congressman David Bowen, a white moderate, urged national Democrats to pursue populism with a "more conservative path on social issues while remaining liberal on economic and governmental issues." He argued that Americans were concerned over crime, broken families, bad schools, and endangered moral values such as discipline, order, patriotism, and religion, and he concluded that the Massachusetts Supreme Judicial Court's legalization of gay marriage was "representative of the moral and cultural issues which defeated John Kerry" (Bowen 2004, 9A, both quotes). MSU political science major Edward Sanders, a Reagan Scholar and an African American, a month before the election was even more blunt, charging that many southerners viewed the Democrats as the party of "abortion, alternative lifestyles, hippies, drug users and radical feminist agenda." Sanders warned national Democratic leaders to "stop treating social conservatives like ideological lepers and make them a part of their "big tent party"' (Sanders 2004, 4, both quotes).

One specific social issue nail in the Democratic presidential coffin was the state constitutional amendment to ban gay marriage, which was backed overwhelmingly by voters in every one of Mississippi's 82 counties (its lowest passage margin was 73 percent in Tunica County). Immediately after the election, state GOP chair Herring observed that "Mississippi values are based on conservative philosophies. Nowhere is this more evident than in yesterday's vote on H.R. 56, a constitutional amendment protecting the 
sanctity of marriage between a man and a woman. The Republican Party fully supported this measure and worked for its passage. In direct contrast, the national Democratic Party's platform supports 'full inclusion of gay and lesbian families,' a position clearly at odds" with Mississippians who overwhelmingly voted for the amendment (Birdsall 2004). Reflecting the national Democratic Party's commitment to the inclusion of gays in their party and its reshaping of state parties, the 2004 Mississippi Delegate Selection and Affirmative Action Plan prohibited discrimination at party meetings based on "sexual orientation" as well as more traditional characteristics such as race, sex, age, national origin, religion, and ethnicity. This state party document also pledged to publicize the delegate selection process "among the Democratic Party's constituencies" in the "gay and lesbian press" as well as in the more traditional minority, ethnic, student, and disability press together with outreach to women's organizations (Mississippi Democratic Party, 2003, 22).

Exit polls showed the importance of ideology in the presidential election, as 81 percent of conservative Mississippians voted for Bush while 76 percent of the few liberals in the state backed Kerry (Table 6). (Unless otherwise indicated, data on various demographic and other voter groups are drawn from the exit poll data from the 2004 National Election Pool, conducted by Edison Media Research and Mitofsky International.) Interestingly enough, though, three other factors were even more highly related to the vote. With a nationally controversial President running for re-election, the contest had become a referendum on his performance in office. Such was also the case in the Magnolia State, as an overwhelming 92 percent of Mississippians who approved of his job performance voted to re-elect him while a similarly huge 95 percent of residents disapproving of his job voted for the challenger. Reflecting the increased intensity of two-party competition in recent years, mentioned at the outset of this article, a near unanimous 94 percent of Republican party identifiers backed Bush while a respectable 85 percent of Democrats supported Kerry. With a plurality of voters in the new Mississippi calling themselves Republicans and a majority of 60 percent approving of Bush's performance in office, Bush's victory is understandable.

The racial divide was also great, as Democrat Kerry earned 90 percent of the African-American vote but only 14 percent of the white vote. Kerry won only 24 of Mississippi's 82 counties, a total even lower than Gore's 25 and Clinton's 30 in 1992 and 35 in 1996. The Democrat won only one white majority county but 23 of the state's 25 black majority counties. Bush swept 56 of the 57 white majority counties and carried 2 black majority counties. Yet even with many of these black majority counties located in the Mississippi River "Delta" region, Kerry was only able to garner 46 percent of the 
102 | Stephen D. Shaffer, David A. Breaux, and Barbara Patrick

Table 6. Demographic and Attitudinal Sources of 2004 Presidential Vote

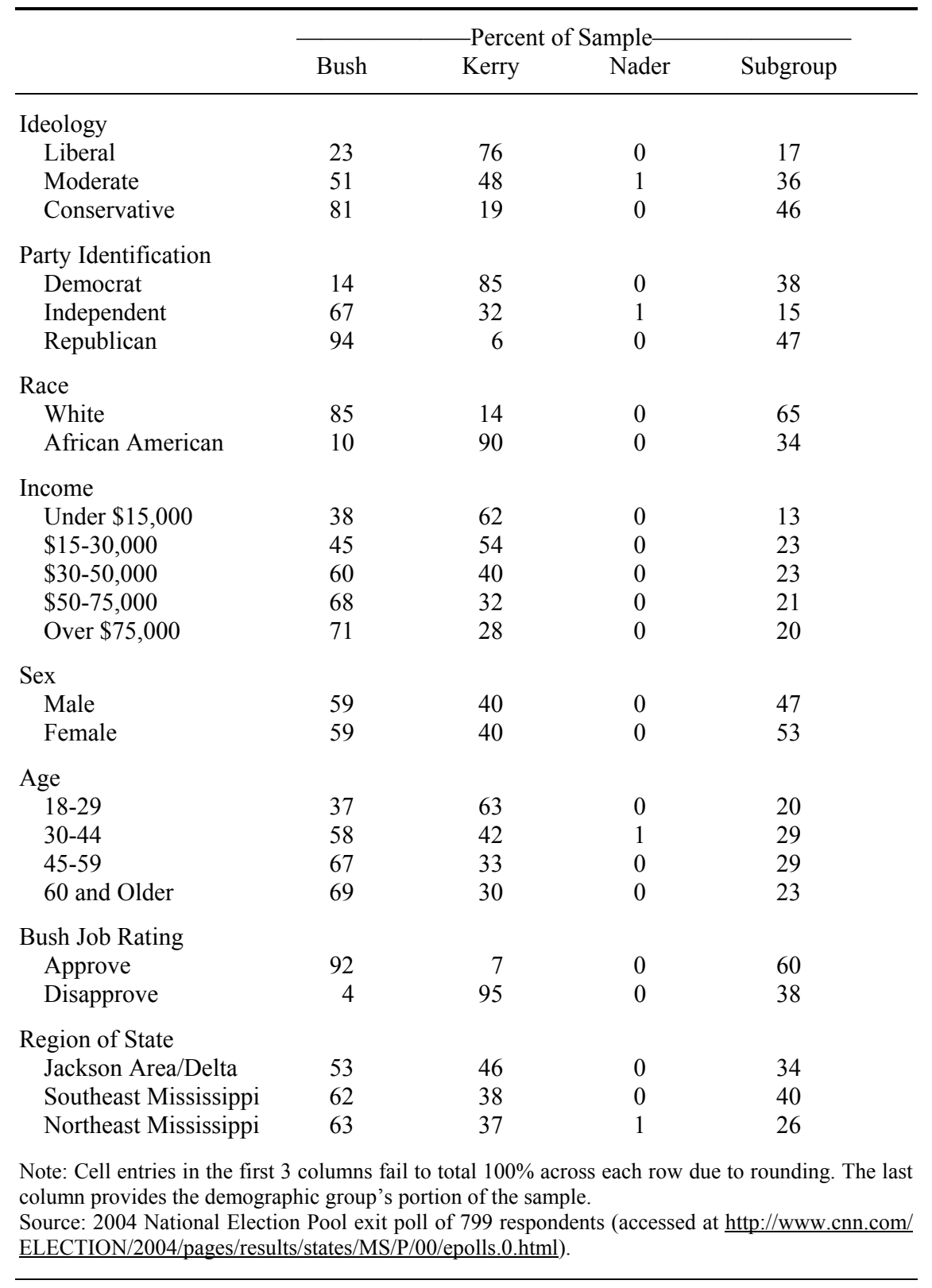


vote of residents in the Delta/Jackson area of the state, as Bush won over 60 percent of voters in the northeast and southeast regions (Table 6). Income and age were also related to the presidential vote, though Kerry won majorities only among voters making less than $\$ 30,000$ annually and those under age 30 , who comprised only 36 percent and 20 percent (with some overlap between the two) of the voting electorate, respectively. As in 2000, but unlike the three previous presidential elections, there was no significant gender gap in Mississippi presidential voting (Shaffer 1991; Shaffer 1994; Shaffer and Burnside 1997; Shaffer and Price 2002).

\section{The Future of Party Politics in the Magnolia State}

Mississippi Republicans in 2004 enjoyed a second good year in a row. After winning half of the statewide elected offices the year before and approaching parity in the state senate, Republicans continued their streak of seven presidential victories, this time reducing the national Democratic ticket to carrying only 14 percent of the white vote and only one majority white county. Yet even in the face of adversity, Mississippi Democrats showed their ability to persevere. Democrats in 2003 retained control of both chambers of the state legislature, re-elected three statewide officers and won an open contest for attorney general, and in 2004 re-elected two long-time congressmen.

Mississippi Democrats are likely to remain competitive in state offices and perhaps even federal elections because of their ability to divorce themselves from the "liberal" national party and to advocate "populism" as defined by former congressman Bowen-conservative on moral and social issues but progressive on domestic economic issues such as education and health care. Congressman Gene Taylor symbolizes this divorce from the national party, having been the only House Democrat to vote to impeach President Clinton on all four articles of impeachment. Mississippi Democratic officeholders are commonly pro-life, pro-guns, pro-military, tough-oncrime, and "pro-God." It is therefore extremely difficult for Republicans to tag them with the "liberal" kiss-of-death label, as the GOP is able to do in presidential elections. As Democrats nationally seek to "redefine" themselves, they would benefit by seeking to learn from the examples of successful Democratic public officials in the so-called "buckle" of the Bible BeltMississippi.

\section{NOTES}

\footnotetext{
${ }^{1}$ See the website http://www.sos.state.ms.us/elections/2004/General/ for Mississippi election results and http://www.cnn.com/ELECTION/2004/ for other states' totals.
} 


\section{REFERENCES}

Abramson, Paul R., John H. Aldrich, and David W. Rohde. 1986. Change and Continuity in the 1984 Elections. Washington, DC: Congressional Quarterly Press.

Aistrup, Joseph A. 1996. The Southern Strategy Revisited: Republican Top-Down Advancement in the South. Lexington: The University Press of Kentucky.

Anderson, Debra. 2003. Andersons Say They're Grateful for the Support. Jackson Clarion-Ledger, November 28.

Associated Press. 2003. Blackmon Says Race Played a Role in Election Defeat. Tupelo Northeast Mississippi Daily Journal, November 7.

Associated Press. 2004a. Barbour Defends Bush Tax Cuts, Takes Shots at Dems. Jackson Clarion-Ledger, February 23.

Associated Press. 2004b. LeSueur Criticized for Billboards. The Greenwood Commonwealth, October 14.

Baker, Margaret. 2004. Union Representatives Urge Votes for Kerry. Biloxi-Gulfport Sun Herald, October 29.

Birdsall, Sally. 2004. Election Day Results: Proof Positive Mississippi is a Republican Stronghold. Mississippi Republican Party website, November 3 press release (accessed at http://www.msgop.org/Strong.asp).

Bowen, David. 2004. Democrats May Remember "Populism" Now. Jackson ClarionLedger, November 11.

Byrd, Shelia Hardwell. 2003. Tuck: Blackmon Proposal Among 'Sleaziest' in History. Jackson Clarion-Ledger, October 2.

Byrd, Shelia Hardwell. 2004a. Edwards' Wife Touts Values at Jackson Fund Raising. Jackson Clarion-Ledger, September 28.

Byrd, Shelia Hardwell. 2004b. Thompson, LeSueur Vie for Congress. The Bolivar CommMercial, November 1.

Cheseborough, Steve. 2004. Thompson Wins Crowd Support. The Greenwood Commonealth, October 29.

Clarion-Ledger, The. 2004a. Ga. Dem Miller Praises Bush at Fund-Raiser. Jackson Clarion-Ledger, October 12.

Clarion-Ledger, The. 2004b. Editorial: President- Kerry No Solution to Bush Mistakes. Jackson Clarion-Ledger, October 31.

Clarion-Ledger, The. 2004c. Editorial: Congress-Thompson Best for 2nd District. Jackson Clarion-Ledger, October 28.

Clarion-Ledger, The. 2004d. Editorial: Congress-Taylor Best for 4th District. Jackson Clarion-Ledger, October 26.

Clark, Ryan. 2004. Clark Talks Iraq, Plugs Kerry Bid in Jackson. Jackson ClarionLedger, May 29.

East Mississippi Business Journal. 2004. "Democrats for Bush" Gather at Capitol. East Mississippi Business Journal, October.

Ervin, Patrick L. 2004. LeSueur Stresses Spirituality at Kiwanis. Greenville Delta Democrat Times, September 8.

Faulkner, Leesha. 2004. Democrats Gather and Bash GOP. Tupelo Northeast Mississippi Daily Journal, October 19 (accessed at http://www.djournal.com).

Fuquay, John. 2004a. Experts Question Edwards' Impact on Miss. Jackson ClarionLedger July 7.

Fuquay, John. 2004b. Miss. DNC Delegates Reflect State's Diversity. Jackson ClarionLedger, July 26. 
Fuquay, John. 2004c. Miss. Delegates Bring Rallying Cry Home from Convention. Jackson Clarion-Ledger, August 1.

Goodman, Julie. 2002. Tuck Switch Embraced by GOP. Jackson Clarion-Ledger, December 3.

Goodman, Julie. 2004a. Kerry Visit Precedes Primary Vote: Subject of Gay Marriages Heats up Hopeful's Tougaloo Appearance. Jackson Clarion-Ledger, March 8.

Goodman, Julie. 2004b. More Medicaid Dollars Must Lead to Extra Services, Pelosi Warns. Jackson Clarion-Ledger, February 20.

Gray, Lloyd. 2003. Musgrove: Attack Ad is "Factual." Tupelo Northeast Mississippi Daily Journal, October 25.

Greenwood Commonwealth, The. 2004a. Editorial: Bush-Good Enough to Give Second Term. The Greenwood Commonwealth, October 31.

Greenwood Commonwealth, The. 2004b. Editorial: LeSueur comes off poorly in debate. The Greenwood Commonwealth, October 29.

Hawkins, Brian. 2004a. Kerry Campaign Chair Rallies Local Dems. Starkville Daily News, May 26.

Hawkins, Brian. 2004b. Cochran: Nation on Right Road with Iraq Rebuilding. Starkville Daily News, September 26.

Hawkins, David, and Brian Nutting, eds. 2003. CQ's Politics in America, 2004. Washington, DC: Congressional Quarterly Inc.

Hudson, Jeremy. 2004. Platoon Defies Orders in Iraq. Jackson Clarion-Ledger, October 15.

Jones, Emily. 2004. Democratic Party Chair Predicts Kerry Will be Second JFK. Starkville Daily News, October 28.

Kanengiser, Andy. 2003. Bush's Work Should Earn Miss. Votes, Cheney Says. Jackson Clarion-Ledger, December 13.

Kanengiser, Andy. 2004a. GOP says Bush Can Bank on Miss. Win. Jackson ClarionLedger, May 16.

Kanengiser, Andy. 2004b. Lott Fires up Neshoba Crowd. Jackson Clarion-Ledger, July 29.

Kanengiser, Andy. 2004c. Barbour Bashes Presidential Candidate at Fair. Jackson Clarion Ledger, July 30.

Kanengiser, Andy. 2004d. Education Chief Praises Bush's Plan for Schools. Jackson Clarion-Ledger, September 1.

Kanengiser, Andy. 2004e. Benefits Restored: Temporary Restraining Order Blocks Medicaid Cuts. Jackson Clarion-Ledger, October 2.

Kanengiser, Andy. 2004f. Notebook: Dowdy Responds to Miller. Jackson ClarionLedger, October 17.

McKenzie, Danny. 2004. Cochran: America "Meeting the Challenge" of Tterror. Tupelo Northeast Mississippi Daily Journal, October 16.

Minor, Bill. 2004a. Gen. Wesley Clark's Dixie Swing Gets Good Send-off in Mississippi. Jackson Clarion-Ledger, January 11.

Minor, Bill. 2004b. Revitalizing State's Democratic Party Goal of Chairman Dowdy. Jackson Clarion-Ledger, July 18.

Mississippi Democratic Party. 2003. Mississippi Delegate Selection and Affirmative Action Plan for the 2004 Democratic National Convention (as of December 17, 2003).

Monroe, David. 2004. Candidates Optimistic About Their Chances. The Greenwood Commonwealth, October 31. 
Pettus, Emily Wagster. 2004a. Kerry Addresses Civil and Gay Rights. Tupelo Northeast Mississippi Daily Journal, March 8.

Pettus, Emily Wagster. 2004b. Kerry-Edwards Served Fried at Neshoba Fair. Jackson Clarion-Ledger, August 3.

Pettus, Emily Wagster. 2004c. LeSueur Gets Brief Turn on GOP Convention Stage. Jackson Clarion-Ledger, August 31.

Pomper, Gerald M. 1981. The Presidential Election. In The Election of 1980: Reports and Interpretations, ed. Gerald M. Pomper. Chatham, NJ: Chatham House Publishers.

Radelat, Ana. 2003. GOP Targets 35 Dems for Defeat, 2 in Miss. Jackson ClarionLedger, December 26.

Radelat, Ana. 2004. Calls Sway Thompson's Vote to Ban Gay Marriage. Jackson Clarion-Ledger, October 7.

Robinette, Aimee. 2004. Candidates Debate 2nd District Issues. The Bolivar Commercial, October 29.

Sabbath, Jessica. 2004. Central Park Plans Get Rained Out. Biloxi-Gulfport Sun Herald, September 1.

Salter, Sid. 2003. Blackmon Falls on Her Sword in Tuck Attack. Jackson ClarionLedger, October 8.

Salter, Sid. 2004. Barbour is Ready for RNC Close-up, But Dems Seek to Change Channel. Jackson Clarion-Ledger, August 31.

Sanders, Edward. 2004. South Not for Democrats Now. Mississippi State University Reflector, October 5.

Shaffer, Stephen D. 1991. Mississippi: Electoral Conflict in a Nationalized State. In The 1988 Presidential Election in the South: Continuity Amidst Change in Southern Party Politics, eds. Laurence W. Moreland, Robert P. Steed and Tod A. Baker. New York: Praeger.

Shaffer, Stephen D. 1994. Mississippi: Friends and Neighbors Fight the "Liberal" Label. In The 1992 Presidential Election in the South: Current Patterns of Southern Party and Electoral Politics, eds. Robert P. Steed, Laurence W. Moreland, and Tod A. Baker. Westport, CT: Praeger.

Shaffer, Stephen D., and Randolph Burnside. 1997. Mississippi: GOP Consolidates Its Gains. In The 1996 Presidential Election in the South: Southern Party Systems in the 1990s, eds. Laurence W. Moreland and Robert P. Steed. Westport, CT: Praeger.

Shaffer, Stephen D., Stacie Berry Pierce, and Steven A. Kohnke. 2000. Party Realignment in the South: A Multi-Level Analysis. American Review of Politics 21:129153.

Shaffer, Stephen D., and Byron E. Price. 2001. Electoral Politics in a Two-Party Era. In Politics in Mississippi, 2nd ed., ed. Joseph B. Parker. Salem, WI: Sheffield Publishing.

Shaffer, Stephen D., and Byron E. Price. 2002. Mississippi: GOP Blunts Democratic Resurgence. In The 2000 Presidential Election in the South: Partisanship and Southern Party Systems in the 21st Century, eds. Robert P. Steed and Laurence W. Moreland. Westport, CT: Praeger.

Smith, Kelly B. 2004. GOP's Herring talks Campaign 2004. East Mississippi Business Journal, October.

Stanley, Harold W. 1994. The South and the 1992 Presidential Election. In The 1992 Presidential Election in the South: Current Patterns of Southern Party and Electoral Politics, eds. Robert P. Steed, Laurence W. Moreland, and Tod A. Baker. Westport, CT: Praeger. 
Stanley, Harold W. 1997. The South and the 1996 Presidential Election: Republican Gains among Democratic Wins. In The 1996 Presidential Election in the South: Southern Party Systems in the 1990s, eds. Laurence W. Moreland and Robert P. Steed. Westport, CT: Praeger.

Stanley, Harold W. 2002. The South in the 2000 Elections. In The 2000 Presidential Election in the South: Partisanship and Southern Party Systems in the 21st Century, eds. Robert P. Steed and Laurence W. Moreland. Westport, CT: Praeger.

Starkville Daily News. 2004. Tuck Talks Politics with Local GOP at Annual Issues Stew. Starkville Daily News, October 3.

Surratt, John. 2004. Congressional Candidates Stump for Votes: Taylor, "I'm An American First.” Pascagoula Mississippi Press, October 15, 2004.

Wheeler, Billy. 2004. Tupelo Attorney Thinks Kerry Can Beat Bush in Mississippi. Tupelo Northeast Mississippi Daily Journal, February 14. 
